\title{
THE LABOUR LEGISLATION REVIEW COMMITTEE'S FINAL REPORT 1987
}

\author{
E. G. FISHER AND JAMES C. ROBB'
}

\begin{abstract}
This article examines the recommendations in the Labour Legislation Review Committee's Final Report 1987 and the corresponding proposed changes contained in Bills 60 and 53, as well as their impact and potential. Key new directions include mandated communications' committees for nearly all workers and greater third-party intervention into collective bargaining, particularly in construction. Should the assumptions upon which the legislative changes are based not be realized, their intent clearly need not be achieved.
\end{abstract}

\section{INTRODUCTION}

During the spring and summer of 1986 a number of major strikes occurred in Alberta. Chief among these were strikes at the Gainers and Fletcher's packing plants, a strike at the Suncor plant, and one involving Zeidler Forest Products Ltd. Of these, only the Zeidler strike remains unresolved. Nevertheless, the strikes may have a lasting effect. Characterized by a high degree of violence, with large numbers of persons being charged with criminal offences, this labour unrest transcended the immediate issues in the strikes. The strikes took on a political flavour, with organized labour alleging Alberta's labour legislation to be the worst in Canada.

Pursuant to the Throne Speech of June 12, 1986, the Government subsequently undertook a comprehensive review of its labour legislation. A committee composed of government, labour, management and public representatives carried it out. The labour relations systems of several foreign countries were examined, including Great Britain, West Germany, the United States, Australia, New Zealand, and Japan. ${ }^{2}$ In February 1987 the Labour Legislation Review Committee issued its final report containing numerous recommendations for reform. As promised, the Minister of Labour introduced the recommendations in bill form ${ }^{3}$ during the spring sitting of the Legislature. Additionally, in Bill 53 the government proposed separate provisions to deal with labour relations in the construction industry. ${ }^{4}$ The overall conclusion of the Report is that the Province of Alberta is well served by its labour legislation which in the main achieves its object of maintaining harmonious labour relations. ${ }^{3}$ The Report indicates that Alberta has very few strikes compared to other jurisdictions. ${ }^{6}$ Nevertheless, numerous reforms are proposed, many of which will substantially change current procedures. While the Report makes no mention of the major labour difficulties in 1986, they clearly form its backdrop. The effectiveness of the Report will have to be measured by the extent to which the recommendations achieve their goals of alleviating or

1. Respectively, Associate Professors, Faculty of Business and Faculty of Law, The University of Alberta.

2. Alberta Labour, Labour Legislation Review Committee Final Report (February, 1987) pp. B8-B28.

3. Labour Code, Bill 60 (1987).

4. Construction Industry Collective Bargaining Act (1987).

5. Supra, n. 3, at pp. iii, 68-83.

6. Ibid., at pp. 8-9. 
eliminating certain perceived labour relations problems. This paper examines the recommendations concerning collective labour relations and the corresponding proposed changes contained in Bills 60 and 53, as well as their impact and potential difficulties.

\section{COMMUNICATIONS, EDUCATION AND INFORMATION BASE}

Concerning communications, the Report suggests that joint labour/ management committees be established in (emphasis added) "all enterprises having twenty or more employees" and that this be done "at the request of the employees, the trade union or employer." Bill 60 provides that the Lieutenant Governor in Council may make regulations requiring the establishment of such committees (s. 9(1)). It will be left to the regulatory power to determine the size and nature of the business to which the regulations apply, as well as the nature of the information that must be made available during the communication or consultation procedures (s. 9(d) and (e)).

Part of the justification for this suggestion is the stability of the labour relations systems the Committee observed in Japan and West Germany. ${ }^{8}$ This recommendation also derives from several of the questions originally posed to the direct participants in Alberta's labour relations system, as well as to the general public. One union had specifically advocated the establishing of Japanese quality circles and West German works councils.' Employers and employers' organizations generally had supported the fostering of communications and, especially, the need for a commonality of interests. ${ }^{10}$ By contrast, unions emphasized their role as exclusive bargaining agents in employee-employer communications, and several viewed employers' concern with strong communications merely as an effort to obtain the right to deal with a "captive audience." The latter, of course, comprises an unfair labour practice during an organizing campaign $^{12}$ and probably would comprise a breach of the duty to bargain in "good faith" during collective agreement negotiations by circumventing the exclusive bargaining agent, namely the certified union..$^{13}$

The improved communications proposal begs several fundamentally important questions about Alberta's union-management or collective bargaining system, its design, its structure, and how it is intended to function. One question is to what extent it is to be an adversarial system, in the sense that the interests of labour and management conflict, and are represented as such at the bargaining table by independent bargaining agents.

7. Ibid., Recommendation 7, at p. 91.

8. Ibid., at pp. $72-74$.

9. Ibid., at pp. 72-73.

10. Ibid., at p. 72.

11. Ibid., at p. 72 .

12. Labour Relations Act, R.S.A. 1980 c. L-1.1, as amended, s. 137(1)(a); Homeware Industries Ltd., [1981] O.L.R. B. Rep. Feb. 164.

13. Labour Relations Act, ibid., s. 73(4); and see B. Bemmels, E.G. Fisher and B. Nyland, Canadian-American Jurisprudence on 'Good Faith' Bargaining (1986) 41 Relations Industrielles 596 at p. 598. 
The Labour Relations Act, as it currently stands, clearly envisages and supports a system of independent bargaining agents, pursuing their own self-interests. Otherwise, there would not be the following: the nonavailability of certification to employer-dominated trade unions (s. 39(1)); exclusions from bargaining units of those exercising managerial functions or privy to confidential labour relations information (s. 1(1)(k)(i)); the duty to bargain in "good faith", including not subverting the exclusive bargaining agent status of the counterpart (s. 73(4)); and other unfair labour practices of restricting individuals or persons on the other side of the bargaining table from exercising the lawful rights conferred upon them by the statute (e.g., the right to participate in the legitimate affairs of their trade union or employers' organization) (ss. 32, 136, 140).

There is a possible tension between the currently existing, adversarial collective bargaining system, which is a reflection of our adversarial legal system, and consultative or cooperative mechanisms like those proposed. This tension has manifested itself in a line of decisions by the National Labor Relations Board (NLRB) in the United States. The NLRB typically has found an incompatibility between collective bargaining and, for instance, cooperative mechanisms having the impact of subverting the other side's bargaining authority, integrity or independence. ${ }^{14}$ This difficulty might be reconciled by the Preamble to Bill 60, which calls for "open and honest communication between affected parties."

Assuming joint cooperation mechanisms could be implemented in a manner compatible with the existing collective bargaining system, one is confronted with the issue of simply engaging in a wholesale adoption of either Japanese quality circles or West German works councils. In the literature on comparative industrial relations this is referred to as the matter of an "institutional transplant." A crude analogy is, "Do we wish to have a Japanese kidney or a West German liver?" The notion of an institutional transplant, in turn, begs the question of whether or not the transplant would be rejected or partially or entirely accepted. To the extent that Japanese quality circles and West German works councils were developed in different historical and cultural settings from ours, it is dubious that they will be entirely accepted in Alberta or Canada. Historically, of course, they were implemented during a period of post-war reconstruction, following large scale destruction and loss of life. Moreover, other important features of the Japanese and West German systems do not exist here, including Japanese enterprise unions, which tend to be very reluctant to engage in strikes, and the West German provision requiring a $75 \%$ vote in favour of a strike as a precondition to a lawful strike. ${ }^{\text {is }}$ Worker participation in management, moreover, might contravene corporate law. ${ }^{16}$

An important ingredient seems to be lacking from the case in favour of improved communications. The Report contained no evaluation of a

14. U.S. Department of Labour, U.S. Labour Law and the Future of Labour-Management Cooperation (1986), and U.S. Labour Law and the Future of Labour-Management Cooperation, First Interim Report - A Working Document (1987) at pp. $42 \mathrm{ff}$.

15. T. Kennedy, European Labor Relations (1980), at pp. 180-181 and R. Blanpain, ed., The International Encyclopaedia for Labour Law and Industrial Relations (1988).

16. First Interim Report, supra, n. 14, at p. 19. 
somewhat low profile program entitled "Preventive Mediation" currently operated by the Mediation Services Branch of Alberta Labour. It consists of: first agreement (negotiations) orientation, joint training (of supervisors and shop stewards), grievance mediation, labour-management committees, and relationship by objectives (RBO).${ }^{17}$ Its components clearly are to improve interfaces among parties at the bargaining table, at the shop floor, in administering collective agreements, and in their overall relationships. Preventive Mediation primarily originated in the United States and clearly was designed to foster better relations in the same processes as those regulated by Alberta's general labour relations statutes. It is a complement to, rather than a potential substitute for, the labour relations system currently operating in Alberta. Arguably, the Report should have focused on Preventive Mediation, including its strengths and weaknesses, prior to recommending a possible institutional transplant.

Another possible weakness to the recommendation for improved communications is that, although the proposal is highly laudible (as a kind of "motherhood issue"), the potential costs and benefits of this proposal are not addressed. In particular, the costs are not assessed relative to the current Preventive Mediation program. The improved communications proposal seems to presume that better union-management relationships than those currently observed can be achieved through legislation. This might be a dubious proposition, given the inherently adversarial and power-relations basis of union-management relationships. Greater evidence of the cost/benefit ratio of implementing the improved communications proposal might be required before embarking upon implementation.

The Report also proposes greater educational efforts in labour relations. It could be that it would be a better means for promoting improved labour relations. Although the Report decries what is perceived as a growing legalistic approach to labour relations, it could be that the system is no more legalistic than it was several decades ago. Moreover, there is a basic legalistic nature to the kinds of labour relations systems developed and implemented in both Canada and the United States. Given this legalistic underpinning to the current system, presumably some labour education sponsorship should cover legal aspects.

A common information base often has been recommended by committees like the Reid Committee. ${ }^{18}$ Its purpose clearly is to provide the parties to negotiations with greater information for improved decision making, especially at the bargaining table. Even if an agency like the Federal Government's Pay Research Bureau were established, its independence and objectivity might be called into question. In the final analysis, the parties presumably would still collect their own information. The Labour Statistics Branch of Alberta Labour, moreover, has been providing bargaining related information through its Collective Bargaining Scene, publication for several years. Furthermore, Labour Canada recently established the Bureau of Labour Information, which is based on the

17. Mediation Services Branch, Alberta Labour, Preventive Mediation (ISBN 0-919943-02-0). The Preventive Mediation program was confined to union-management relationships; whereas, communications mechanisms in Bill 60 are to be universally available.

18. For instance, Nemetz, J. made such a recommendation in the late 1960 's in British Columbia in his Report of Swedish Labour Laws and Practices (1968), at p. 11. 
American Bureau of Labor Statistics and became operational during 1987 following the Report's release.

At a higher policy level of communication is a "Roundtable Conference", to be comprised of "representatives of business, trade unions, the academic community and any other groups" the Minister considers "advisable for the purposes of developing a general understanding of Alberta's economic circumstances and those factors critical to continued economic growth." 19 Given its rather broad mandate it is too early to speculate about its effectiveness. The precedence for such bodies existed and functioned in Alberta's construction industry. ${ }^{20}$ On the one extreme, it could simply represent an Alberta duplication of the Economic Council of Canada, and there is the possibility of its being rejected by organized labour as another form of the tripartism it rejected in the mid-1970s. Nevertheless, any attempt to improve our understanding of Alberta's regional economy and her own particular industrial relations system should be welcomed.

\section{CERTIFICATION PROCESS}

Important new changes are proposed for the certification and revocation of certification process. the importance of the subject area cannot be underestimated, for as Adams has stated:21

The certification process is at the heart of any system of collective bargaining and has a fundamental impact on labour relations.

At present, every jurisdiction in Canada but two permits certification upon documentary proof of unit support without the necessity of a vote. ${ }^{22}$ This typically means that at least a certain threshold percentage of members of the "appropriate bargaining unit" have indicated their preference for a particular trade union either by applying to join it or joining it and paying a nominal fee for membership. In British Columbia, upon proof of at least $45 \%$ support of the bargaining unit, a certification appliction may be considered but not granted without a vote. ${ }^{23}$ In Nova Scotia, a representation vote is also required. ${ }^{24}$ Ontario permits certification upon documentary proof of $45 \%$ support, although a pre-hearing vote may be requested upon proof of $35 \%$ support. ${ }^{25}$ In the rest of Canada, while the level of support that is required varies, upon proof of the requisite level of support, a Board may certify. Majority support currently is required in Alberta. ${ }^{26}$

19. Supra, n. 3, s.8.

20. E.G. Fisher and S. Kushner, Alberta's Construction Labour Relations During the Recent Downturn (1986), 41 Relations Industrielles 778, at p. 794.

21. G. Adams, Canadian Labour Law (1985), at p. 309.

22. Ibid., at p. 355.

23. B.C. Labour Code, R.S.B.C. 1980, c. 212, as amended by Industrial Relations Reform Act 1987 (Bill 19), s. 43.

24. Trade Union Act, S.N.S. 1977, c. 70, s. 24.

25. Labour Relations Act, R.S.O. 1980, c. 228, s. 7(2).

26. Labour Relations Act, supra, n. 12, s. 38(2). The Nova Scotia's supreme Court recently ruled that the Nova Scotia Labour Relations Board violated the principles of fundamental justice by refusing to release the figures of certification votes or allow scrutineers access when counting votes (Britex Ltd. v. United Steel Workers of America, Local 9181 et al., [1987] Lawyers Weekly 738-005. 
The Report and Bill 60 propose that Alberta join British Columbia and Nova Scotia in requiring a vote prior to certification regardless of the level of support demonstrated. ${ }^{27}$ The mandatory vote is based on the American "democracy" principle contained in the National Labour Relations Act. ${ }^{28}$ The Report's rationale is for changing the certification process as follows: ${ }^{29}$

This process is essentially a matter for the employees. It should be free of undue influence or coercion by the employer and trade union(s) attempting to organize those employees.

Concerns were heard by the Committee regarding access to workers at isolated worksites, disputes about the appropriate bargaining unit causing undue delays, and the need for reasonable speed in the process.

There were also comments regarding the "life" of the membership card, the fee, and the percentage of support required.

Since there should be an ongoing relationship between employer and employee and since the current system of certification on occasion causes considerable friction, changes should be made.

In fact, the vote requirement will slow the process down and may cause more friction than at present. The conventional wisdom of unions is to try to organize in a manner that does not alert the employer. The employer is entitled to express views on unionization as a matter of free speech, provided it is not perceived as coercive.$^{30}$ What is feared by unions is not the exercise of free speech but rather the disguised coercive tactics used by employers, such as dismissals of union organizers. While this would be an unfair labour practice, three problems for unions would arise: (1) in the absence of blatant anti-union animus, such cases are difficult to prove,$^{31}$ (2) such votes would prolong the certification process, and (3) while Bill 60 retains the Labour Relations Board's discretion to certify without a vote, if the unfair labour practice were proven, the Board has indicated a reluctance in the past to use this remedy. ${ }^{32}$ Indeed, labour boards across Canada have been loathe to exercise such discretion in the absence of overwhelming evidence that the unfair labour practice would prevent a true vote from being held. ${ }^{33}$ In short, a required representation vote generally would permit employers greater opportunity to resist unionization.

27. Final Report, supra, n. 2, Recommendation 38, at p. 100; Labour Code, supra, n. 3, ss. 144145.

28. B. Taylor and F. Witney, Labour Relations Law, (1987) at pp. 161ff. Curiously, Bill 60 proposes one radical departure from the "democracy principle." Section 148(2) singles out five fighter units, proposing that officers from captain rank upward be represented by a separate bargaining agent contained in $5.120(b)$, this would require a separate trade union to represent higher officers and not simply a separate bargaining unit. Undoubtedly, this will lead to a challenge under s. 2(d) of The Charter of Rights and Freedoms. In Ref. re P.S.E.R.A. (1987) 1 S.C.R. 313 the Court gave a narrow interpretation to s. 2(d), indicating it included the right to belong to an association but did not extend to protecting collective bargaining.

29. Supra, n. 2, at pp. 99-100.

30. Alberta Bill of Rights, R.S.A. 1980, C.A.-16, s. 1(d); O.C.A.W. v. Syncrude, 78 C.L.L.C. 16, 168 (Alberta B.I.R.).

31. T.A.S. Communications Ltd. (unreported, B.I.R. No. 234) (Alberta B.I.R.).

32. Ibid.; a rare instance in which the discretion was exercised followed upon proof of a disregard of a previous Board order and overwhelming evidence of coercive tactics: see United Food and Commercial Workers International Union Local 401 et al. v. Mariposa Stores Ltd., [1986] Aita. L.R.B.R. 661 .

33. Adams, supra, n. 21 , at pp. $390 \mathrm{ff}$. 
A further detail not provided by the Report or Bill 60 is who would be entitled to vote: would they be employees as of the date of the application, or some other terminal date? ${ }^{34}$ The current British Columbia, Ontario and longstanding American experience indicates that this is critical, as the hiring of fresh employees may well influence the outcome of the vote, ${ }^{35}$ particularly employees hired during the currency of a strike or lockout who may apply for decertification.

A further recommendation also may prove problematic to unions. The Report's solution to resolving disputes over what constitutes an appropriate unit is to place the onus on the union in the original application. Recommendation 37 requires the Board to determine whether the appropriate unit is reasonably similar to that applied for by the union. If it is not, the application must be rejected, and the union and employer so advised. At present the Labour Relations Baord has the discretion to amend the unit description. ${ }^{36}$ Following the Report, Bill 60 proposes that this discretion may be exercised only when the altered or amended unit would be reasonably similar to the unit originally claimed by the trade union (s. 148(1)(f)). Its importance is, as Adams notes, that it is common for an employer to object where the union has applied for a larger unit, arguing for a smaller unit; and where a small unit has been applied for, arguing for the larger unit. ${ }^{37}$

In the final analysis, there is little, if any, room for error. At present, the Board has the authority to amend an application which would appear to provide flexibility in keeping with the labour-relations purposes of the Act. Yet, neither the present Act nor Bill 60 provide any specific criteria for determining what is an appropriate unit. While the Labour Relations Board has started to issue policy bulletins describing what would normally be acceptable, this process is far from complete. ${ }^{38}$ Nevertheless, the commendable practice of issuing information bulletins, when completed, should alleviate problems of this nature.

A provision of Bill 60 which undoubtedly will raise the ire of unions is the proposal for a religious exemption. By s. 140(1) a trade union and employer may agree that all employees are required to be members of a trade union (a union or closed shop agreement). However, by s. 140(2), if the Board is satisfied that an employee because of religious conviction or belief objects, the Board may order that the union security provisions of the collective agreement do not apply. An employee thereby exempted would not be required to be a member, and an amount equivalent to union dues would be paid to charity (s. 142(2), (3)). This section is not free from ambiguity. It would seem that the exemption will not apply, if the collective

34. S. 145(1)(d) simply provides for a vote of the employees in the unit considered by the Board to be an appropriate unit. S. 127(3)(c) provides that the Labour Relations Board may determine who is eligible to vote.

35. Adams, supra, n. 21, at p. 357. In Employees Stealman Marketing Consultants et al. v. Retail Clerks Union, Local 151885 C.S.S.C. 16, 030, the B.C.L.R.B. held that replacement workers could not vote on an application for recertification as they had no continuity of interest with those who were on strike.

36. Labour Relations Act, supra, n. 12, s. 37(2)(b).

37. Adams, supra, n. 21, at pp. 310-311.

38. Labour Relations Board, Information Bulletins No. 3-82, 4-82, 5-82, 9-82, 11-82, $12-82$. 
agreement contains a Rand formula rather than a closed or union shop. If that is the correct interpretation, then it will be the construction trade unions which will be most affected, since union or closed shop arrangements tend to be more typical in that industry. ${ }^{39}$

The proposal does not have its roots in the Report; consequently, the rationale for it is difficult to discern. Ontario has a religious exemption provision $^{40}$ and the Ontario Board has given a broad interpretation to it, permitting subjective conviction to govern and not requiring proof that formal religious tenets require the exemption. ${ }^{41}$ It is a controversial provision and most likely will be viewed by Alberta labour as the first incremental step towards so-called right to work legislation.

\section{COLLECTIVE BARGAINING PROCESS}

This subject represents one of the most controversial areas in Alberta labour policy, largely because it impacts upon the relative bargaining power of parties to a collective agreement. Currently, upon the expiry of the term of a collective agreement, an employer is free to lock out employees, and a union may apply for a strike vote, or an employer's organization for a lockout vote, provided there has been good faith bargaining. ${ }^{42}$ If the collective agreement has a "bridging clause" (a clause which provides for the continuation of the collective agreement during the course of collective bargaining), the agreement may be terminated by a strike or lockout, ${ }^{43}$ or if bargaining has reached impasse. ${ }^{44}$ Alternatively, if there is no bridging clause, the agreement can be terminated upon expiration, provided that appropriate termination notice, if required, has been served properly. ${ }^{45}$

A practice which has developed in Alberta is that upon impasse an employer declares a 25-hour lockout. Once the lockout occurs, the employer is free to establish terms and conditions of employment. While the employees cannot be compelled to return to work under the newly created terms, the employer can hire replacements, including those

39. Alberta Labour, Negotiated Working Conditions in Alberta Collective Agreements, (1984) at p. $175 ; 80.5 \%$ of the construction unions had closed shop agreements and $17.1 \%$ had union shop agreements.

40. Labour Relations Act, n. 25, s. 47; other statutes having a similar provision are B.C. Labour Code, n. 23, s. 11; Man. Labour Relations Act, S.M. 1972, C. 75, s. 68(3); Sask. Trade Union Act, R.S. Sask. 1980, c. T-17, s. 5(b); and Labour Code Canada, R.S. 1970, c. L-1, as amended, ss. 162-164.

41. See Adams, supra, n. 21, p. 270-792. In Manitoba the provision has been applied more stringently; however, in a recent decision the Canada Labour Relations Board ruled that a person who did not belong to any religious organizations but held religious beliefs as a matter of personal conscience qualified for the exemption. See: Guertin v. C.P.A.A. et al, (unreported, March 16, 1987).

42. Labour Relations Act, supra, n. 12, s. 87.

43. Operating Engineers v. Alberta Roadbuilders Association (1984) 53 A.R. 355 (Alta. C.A.).

44. International Association of Bridge, Structural and Ornamental Ironworkers v. Arrow Steel Industries Ltd. (1985), 65 A.R. 253 (Alta. Q.B.); United Food and Commercial Workers International Union, Local $312 \mathrm{~A}$ v. Edmonton Co-operative Association (unreported, File No: L.R. 202-E-1) (Alta. L.R.B.).

45. Construction Labour Relations Association v. United Association of Journeyman and Apprentices of the Plumbing and Pipefitting Industries Local 496(1984), 34 Alta. L.R. (2d) 229 (Alta. Q.B.), (1985) 37 Alta. L.R. (2d) 1 (Alta. C.A.). 
members of the work force who voluntarily agree to return to work under the new terms ${ }^{46}$ At any time, the relative bargaining strength of the union is dependent upon the availability of a replacement work force (the lower the skill level or the higher the unemployment rate for a skilled trade, the more likely replacement is possible). Thus, the union has considerable relative bargaining power vis-a-vis employers during times of economic upswing or prosperity, and vice versa during periods of economic decline or recession. This state of relative bargaining strength impacts not only at the time of lock out but also during the earlier bargaining period as well. During economic decline, the only perceived alternative for a union is to shut down the plant with an effective picket line to attempt to prevent the replacements from working. Invariable in practice, this requires words or conduct beyond mere "persuasion" and would be construed as "acts otherwise unlawful" prohibited by the Act, resulting in an injunction. ${ }^{47}$

Neither the Report nor Bill 60 proposes to end the 25 -hour lockout. Rather, its solution is to lengthen the collective bargaining process and place more hurdles in the path of strikes and lockouts. This would be achieved as follows:

1. Notice to commence collective bargaining must be served 60 to 120 days prior to the expiry of the collective agreement. ${ }^{48}$ This is an increase from the current 60 to 90 days..$^{49}$ It is clear from current case law that it would not be possible to contract out of this provision..$^{30}$

2. Within $\mathbf{3 0}$ days of service of the notice, the other party would have to provide a list of authorized participants in bargaining. In not less than 10 days and not more than $\mathbf{3 0}$ days from service of notice, the parties must meet and commence collective bargaining. ${ }^{51}$ To this point, it would seem that collective bargaining would commence earlier and potentially conclude sooner than at present. However, further proposals could serve to build in delay.

3. At the first negotiating session the parties must exchange detailed, particularized proposals in relation to every matter in dispute. Additions to the respective bargaining packages subsequent to the initial exchange could be made only by mutual consent and only within the package if the changes relate to the matters in dispute at the time of the initial exchange, or by mutual consent..$^{22}$

This requirement for virtually full disclosure at the outset seems to force the parties to address all issues earlier on in the dispute and prohibit "accelerated demands" or the "receding horizon", which presently is

46. E.G. Fisher and S. Kushner, supra n. 20, pp. 789-793; United Food and Commercial Workers, Local 280-PN. Gainers Inc., [1986] Alta. L.R.B.R. 529.

47. Labour Relations Act, supra n. 12, ss. 112, 114; International Union, United Automobile Aeraspace and Agricultural Implement Workers et al. v. Pacific Western Airlines Ltd. (1986) 70 A.R. 67 (Alta. C.A.); International Association of Heat and Frost Insulators, Local 126, et al. v. Edinburgh Developments Ltd. 74 C.L.L.C. 14, 238 (Alta. S.C.A.D.); S. Tacon, Tort Liability in a Collective Bargaining Regime (1980).

48. Labour Code, supra, n. 3, s. 172(2).

49. Labour Relations Act, supra, n. 12, s. 74(2).

50. Edmonton Co-operative Association, supra, n. 44.

51. Labour Code, supra, n. 3, ss. 173-175.

52. Ibid., ss. $175(1)(b)(2)$. 
governed by the good faith bargaining provision in the Act..$^{33}$ The latter, however, presumably would continue to preclude a widening of positions in future under the proposed legislation in much the same manner as it currently does. Presently, an accelerated demand is not necessarily bargaining in bad faith, if justified by evidence of changed economic circumstances. For example, an employer may reduce a wage offer, if it can be shown that during the course of negotiations, either prior to or during a lawful work stoppage, contracts have been lost or profits declined. In such cases, the view has been that the employer has not exhibited the necessary intention to destroy the bargaining framework. ${ }^{.4}$

While the proposed full disclosure at the outset should expedite bargaining, the opposite might result from the polarization of positions it may foster. The parties would have to ensure that their list of bargaining items is complete in order that changes can be made on matters in dispute. This requirement could make virtual "laundry lists" of proposals the norm. Nevertheless, it is preferable to the Final Report's proposal (Recommendation 24(c)) which would have forbidden any changes to position unless they were "within" the initial package. That would have required each side's complete set of initial proposals to anticipate subsequent events such as a strike or lockout. A union, for example, might have to request a signing bonus in the event of a strike in its initial request. Similarly, an employer would have to propose a reduced wage position in the event of economic difficulty. The results may well have been disasterous.

4. The Report and Bill 60 propose that any time following the exchange of proposals, either side may on one occasion only apply to the Labour Relations Board for a vote on a last offer. Before ordering a vote, the Board must be satisfied that, if accepted, the final offer could form the basis for a collective agreement..$^{55}$ While this would have the beneficial effect of preventing a party from misrepresenting an offer to those it represents, ${ }^{36}$ the voting process would extend the bargaining process.

5. The Report proposed that there be a minimum of 60 days bargaining, followed by compulsory conciliation procedures, followed by a compulsory 14-day cooling off period. ${ }^{57}$ Bill 60 does not contain the minimum bargaining period, nor does it require conciliation or mediation per se. Instead, it provides that either or both parties may request the appointment of a mediator at any time after notice to commence collective bargaining is served (s. 177(1). Alternatively, the Minister may direct the appointment of

53. Labour Relations Act, supra, n. 12, s. 76(3). In Graphic Arts International Union v. Graphic Centre (Ont.) Inc. 76 C.S.S.C. 16,274 it was held by the Ont. L.R.B. that the first negotiation session must establish the parameters of collective bargaining. The "holding back" of demands would destroy the bargaining framework.

54. United Steelworkers, Local 9011 v. Radio Shack (1986) C.L.L.C. 16, 006 (Ont. L.R.B.); International Association of Machinists and Aerospace Workers, Local 2913 v. General Aviation Services Ltd. 82 C.L.L.C. 16,177 (Can. L.R.B.).

55. The vote can be on a simple majority of individual votes or on a weighted basis for employers' organizations (s. 176). Again, the problem of whether replacements may vote will arise. See Steadman Marketing, supra, n. 35.

56. The Report emphasized that the union local membership should be involved in collective bargaining decisions, supra, n. 2, pp. 95-96.

57. Supra, n. 2, Recommendation 24, pp. 96-97. 
a mediator, such as at present. Additionally, if a new collective agreement is not concluded after 60 days from the exchange of proposals, a mediator may be requested or the Minister may require the appointment of one (s. 178(1)). The mediator may recommend terms of settlement, recommend the appointment of a mediation board or make no recommendation while booking off the case, thereby creating the possibility of a lawful work stoppage (s. 178(5)).

If a mediation board is recommended, the Minister may require the parties to continue negotiations or refer the dispute to a mediation board (s. 179). The board would have 20 days (or a longer period, if agreed to by the parties or fixed by the Minister) in which to effect a settlement or make recommendations with respect to each item in dispute. The parties would have 10 days to accept or reject the recommendations of a mediator or mediation board (s. 181(1)). If not accepted, the Labour Relations Board must hold a supervised vote on the recommendations, apparently even if the recommendations are rejected by the employer, which would make the holding of a vote redundant. Moreover, it is not clear who is to be polled in a firm: the shareholders, board of directors, personnel manager, or a group of managers?

6. Both the Report and Bill 60 propose a deemed bridging clause in every collective agreement..$^{58} \mathrm{~A}$ collective agreement could be deemed to be in force until a new collective agreement is concluded or a strike or lockout (i.e., a lawful work stoppage) commences (s. 242(1)). The importance of this provision cannot be understated. Currently, a bridging clause will continue a collective agreement until a strike or lockout or an impasse in bargaining. ${ }^{59}$ The proposal will create a bridging clause for every collective agreement, and reaching a legitimate impasse, in and of itself, will not end the agreement. The next step of commencing a strike or lockout must have been attained. If the mediation process is used, it could stave off a lockout or strike conceivably for a lengthy period of time. This has occurred in other jurisdictions..$^{60}$

7. In addition, a request for a strike or lockout vote may not be made until at least 14 days after the date on which the applicant is notified about the result of a vote on an of fer or the results of mediation. Even in the case of a single employer, an application to the Labour Relations Board would have to be made and the employer polled by the Board (s. 184(2)).

8. Unlike the present, the parties may request more than one strike or lockout vote, provided at least 90 days have expired from the last vote. If no strike or lockout occurs within 90 days of the vote, the vote is deemed to

58. Ibid., Recommendation 24(f), p. 96; Labour Code, supra, n. 3, s. 242(1).

59. Operating Engineers v. Alberta Roadbuilders Association, supra, n. 43; United Food and Commercial Workers International Union, Local $312 A$ v. Edmonton Co-operative Association, supra, n. 44.

60. Indeed, an impending strike by the Vancouver Policeman's Union in 1974 was staved off by not allowing the mediator to book off the case under the statutorily deemed bridging clause. The parties, thereby, were precluded from engaging in a lawful work stoppage and induced to agree to mediation-arbitration with a different third party. See: E.G. Fisher and H. Starek, "Police Bargaining in Canada: Private Sector Bargaining, Compulsory Arbitration and Mediation-Arbitration in Vancouver," in B.M. Downie and R.L. Jackson, eds., Conflict and Co-operation in Police Labour Relations (1980) at pp. 46-47. 
be void. The parties would then have two years from the end of the 14-day cooling off period to apply for another such vote (s. 186).

The Report must be viewed as a package and not just as a series of discrete proposals. ${ }^{61}$ The underlying premise or gamble appears to be that, should economic recovery be achieved in Alberta and better communications between labour and management be fostered, perceived unionmanagement problems will largely resolve themselves. The extended bargaining process would then help to resolve the few remaining labour disputes.

The overall frailty of the proposals is that, should one of the major assumptions prove to be unfounded, the extended bargaining process will solve little and may prove to be a further source of frustration. For instance, there seems to be the underlying presumption that government supplied third parties (i.e., mediators or conciliators) will be able to exert greater realism on the parties. This presumption, however, arguably reflects an incomplete understanding of the mediation/conciliation process.

The mediator's primary objective of achieving a settlement is not necessarily consistent with bringing pressures to bear upon the parties to be realistic. Moreover, such a role places the mediator in a position of judging the relative merit of the parties' positions, just as an arbitrator would do. By contrast, to achieve a settlement, the mediator must operate at the same level as the parties, reflecting their concerns and positions, and conveying them to the other side through the bargaining process, not above it. In the final analysis, a mediator will not gain a settlement, unless the parties are prepared to settle. ${ }^{62}$ This is one of the key reasons why compulsory conciliation procedures were removed from Alberta's labour law in 1980.

In summary, there are at least three important features to the expanded time frame during which a collective agreement could be in force well beyond its expiry date. First, under current labour law, even with a bridging clause, a lawful strike or lockout could occur within one week or so of expiry; second, the envisaged time frame clearly is much longer, and its longer duration may provide greater legitimacy to current terms and conditions of employment. Third, employees, accordingly, will have a longer time period for access to and coverage by the compulsory grievance handling machinery.

\section{REPLACEMENT WORKERS AND PICKETING}

The Report proposes that current provisions of the Act relating to employment status during a strike or lockout be combined to provide a definitive statement that such workers have a right to their jobs. ${ }^{63}$ Currently, s. 1(2) of the Labour Relations Act provides that no person loses employment status by virtue only of ceasing to work as the result of a lawful strike or lockout. S. 137(3)(a) prohibits the dismissal of workers for participating in a lawful strike or lockout.

61. Supra, n. 2 at p. 89-90.

62. W.A. Maggiolo, Technique of Mediation (1985), at pp. 91-103.

63. Supra, n. 2, Recommendation 25, at p. 98. 
Under Bill 60, once a strike or lockout ends as a result of settlement or termination of bargaining rights, or on expiration of two years from the commencement date of the strike or lockout, an employee is entitled upon request (presumably placing the onus on the employee) to resume employment in preference to a replacement employee (s. 203). This provision is subject to any return to work agreement arrived at by the employer and union (s. 203(2)), much as in Manitoba. ${ }^{64}$ Additionally, professional strike breakers are prohibited (s. 262(3)(h) and (5)). This might inhibit or prevent the setting up of companies which intend to supply strike breakers. ${ }^{65}$ However, it would not prevent labour brokers from supplying labour, unless the Board is of the view that its primary object is to prevent, interfere with, or break up lawful union activities (s. 5). This is a mens rea requirement that would be extremely difficult to prove.

While the right of employers to hire replacements has never been doubted at common law, ${ }^{66}$ and few jurisdictions prohibit their hiring or provide for a right to return to work by statute ${ }^{67}$ there has been considerable controversy as to whether an employer could hire permanent or temporary replacements. ${ }^{68}$ Despite recognizing that the threat of permanent replacement will often incite ugly picket line violence, the Ontario Board adopted the American position that absent the statutory protection afforded by s. 64 of the Ontario Labour Relations Act, a striking employee choosing to return to work must await a vacancy to occur and could not demand the creation of one by dismissal of a replacement. The Alberta and Canada Boards here, in sharp contrast, ruled that replacements are temporary only and that once a strike has ended (a union may concede defeat and unilaterally end the strike) the employees normally must be returned to work. ${ }^{69}$ Nevertheless employees in Ontario, may return to work within six months of the commencement of

64. Man. Labour Relations Act, supra, n. 40, s. 11(1).

65. M. Zwelling, The Strikebreakers (1972).

66. C.U.P.E. v. New Brunswick Liquor Corporation, 79 C.L.L.C. 14,209 (S.C.C.); O.P.S.E.U. v. Mini-Skool Ltd., 83 C.L.L.C. 16, 065 (Ont. L.R.B.).

67. S. 102(3)(a) of the New Brunswick Public Service Labour Relations Act, R.S.N.B. 1973, c. P. $25, \mathrm{~s} .19$ prohibits the hiring of any employees during a public sector strike; in Quebec, the hiring of replacements in any strike is prohibited (Labour Code), S.Q., 1977, c. 41, s. 97a). In Manitoba an application to the Board to settle the terms of a first collective agreement ends the strike and employees must be returned to work in order of seniority (supra, n. 64, s. 75.1(5); and in all other cases, if a strike results in a collective agreement it must contain a back to work clause or otherwise the employees are to be returned to work in order of seniority as work becomes available (supra, n. 64). Ontario provides that within 6 months of the commencement of a strike, a striking employee has a right to return to work even if that necessitates the termination of a replacement employee (supra, n. 25, s. 64). However, the right must be exercised before the strike has ended (See: Becker Milk Co. v. Ind. Ex Distributors, 78 C.L.C.C. 16,123 (Ont. L.R.B.).

68. O.P.S.E.U. v. Mini-Skool, supra, n. 66; N.L.R.B. v. Mackay (1938) 2 L.R.R.M. 610 (U.S.S.C.).

69. In International Association of Machinists \& Aerospace Workers et al. v. Nordair et al., 85 C.L.L.C. 16,051 (Can. L.R.B.) the Board held that there is no obligation for an employer to take striking employees back to work while the strike is ongoing. However, in International Association of Machinists \& Aerospace Workers, Local 2431 v. General Aviation Services Ltd., 82 C.L.L.C. 16,177 (Can. L.R.B.) it was held that once the union concedes the employer's position and unequivocally acknowledges defeat, a refusal by the employer to take back striking employees is bargaining in bad faith. The Alberta position is similar: see International Brotherhood of Boilermakers v. Maloney Steel Ltd., [1986] Alta. L.R.B.R. 798. 
the strike provided the strike is still ongoing. In Alberta and the federal jurisdiction there exists a right to return to work after the strike is unequivocally ended.

Bill 60 does not purport to alter the current Alberta case law but does create two difficulties. By s. 203 a strike will be deemed ended if an agreement is signed, one of the parties' bargaining rights are terminated or two years have elapsed since the commencement of the strike. Additionally, the parties are free to conclude a back to work agreement. As a result of the two year waiting period, the only voluntary means of obtaining jobs back will be to win the strike or concede to the employer's terms inducing a win at all costs attitude. Second even if conceding defeat, a union would likely be faced with bargaining proposals for return to work which will delay the process and may be highly unpalatable. This has occurred in the past $^{70}$ and can make unions resist conceding defeat.

The major premise of the new provisions is that the striking or locked out employee retains employee status. However, neither the Report nor Bill 60 addresses the critical issue of what will terminate employment status, thus rendering the new provisions inoperative. Dismissal for misconduct would still be available to the employer. " The more controversial question is whether obtaining alternative employment during the course of the strike or lockout will sever the employment relationship. ${ }^{72}$ Arguably, the 2-year period would be interpreted as contemplating alternative employment, but the current case law is rife with controversy and contradiction. There is a disagreement whether the test for determining that taking alternative employment is a form of "quit" is objective, subjective or a combination. ${ }^{33}$ The question of onus of proof has yet to be finally resolved. ${ }^{74}$

A more controversial recommendation contained in the Report, but not in Bill 60, is that replacements be paid an amount equivalent to wages and benefits contained in the old collective agreement, should the employer be found to be bargaining in bad faith. ${ }^{75}$ The difficulty with the recommendation is that it assumes that the replacements will be paid less than the workers prior to the strike or lockout. In bad economic times that is the practical result. If the issue causing the strike or lockout had been an employer's position of reducing wages, and the union had proposed maintaining pre-existing contractual rates, the effect of the provision

70. U.N.A. v. Hardisty Nursing Homes, unreported, (Alta. L.R.B.).

71. Bill 60, supra, n. 3, s. 266.

72. In C.P.R. v. Zambri (1962), 34 D.L.R. (2d) 655 (S.C.C.), Locke, J. indicated that statutorily protected employment status could end if a striker has "taken employment with the employers" (at p. 657). The Ontario Board has held that taking permanent employment is a quit. See: J. McLeod \& Sons Limited, [1969] O.L.R.B. Rep. 1100; and Becker Milk, supra, n. 67 at p. 16,886 .

73. The Ontario position ibid. appears to be that it is an objective test, while in Alberta Manning, J. held in Texaco Canada Limited v. O.C.A.W., Local 9-910, 78 C.L.L.C. 14,125 (A.G.C.T.D.) that it was both an objective and subjective test although on the facts it appeared that the subjective test predominated. In any event, a purely objective test was rejected.

74. See Adams, supra, n. 21, at p. 621, 660-661 and A.W.R. Carrothers, E.E. Palmer and W.B. Rayner, Collective Bargaining Law in Canada, 2nd ed. (1986), at pp. 170-173.

75. Supra, n. 2, Recommendation 26, at p. 98. 
would be to hand a win to the union. Bargaining unit members could call a strike and simply return to work at their old rates. Such a response would raise the issue whether or not the Labour Relations Board would designate their ruling as (1) applying solely to "replacements" from outside the bargaining unit or (2) as being restricted in time, namely to the time period between the beginning of the strike and the return of the bargaining unit to work.

It is lamentable that there is no specific remedy in Bill 60 for bad faith bargaining where replacement workers are involved in a lawful work stoppage. Indeed, labour legislation should provide remedies, whatever the economic times. In a period of economic upswing, it is conceivable that an employer might pay the same rate, or even better rates, than at the time of the strike or lockout. By limiting the employer to old agreement compensation packages and, thereby, effectively capping replacement workers' wages, this recommendation would hamper the hiring or retention of replacements. One alternative would be to permit the Board to order compulsory arbitration, should one or both of the parties have been bargaining in bad faith. ${ }^{76}$ Arbitration, at least, would establish a presumably fair wage where the bargaining framework has been destroyed and preclude ugly picket line incidents, as well as controversies as to whether or not replacement workers are over-paid or under-paid at old agreement rates, relative to emerging market forces.

\section{PICKETING}

The Report proposes that the present ban on secondary picketing continue, and that the jurisdiction of the courts to control the conduct of picketing though the various tort actions continue. ${ }^{\pi}$ Interestingly, Bill 60 proposes to limit somewhat the jurisdiction of the courts. By s. 204 no court shall grant an injunction or other process to restrain or limit strike or picketing activities when: (a) there is a reasonable likelihood of danger to persons or property; (b) resort to the Board is impractical, in which case an order may be obtained, but such an order would be effective only until the Board could deal with it; and (c) the Board has decided the matter and it is found that an order of the Board has been contravened.

This may, in future, mean that labour relations considerations rather than tortious concepts, may become the primary consideration, since the Board is intended to be the primary source of restraint orders. ${ }^{78}$ While the courts are not completely ousted, their jurisdiction would be more limited than at present and might prevent the type of interim injunction granted in International Union, United Automobile Aerospace and Agricultural Implement Workers of America et al v. Pacific Western Airlines Ltd. ${ }^{79}$

76. This was the result in Eastern Provincial Airways Ltd. v. C.L.R.B., 84 C.L.C.C., 14,042. (F.C.A.). The court upheld a tribunal decision directing striking employees back to work (and the employer to take them back) and submit their dispute to arbitration in circumstances where the Board determined that both parties had been guilty of bargaining in bad faith.

77. Supra, n. 2, Recommendations 32-33 at p. 99.

78. See S. Tacon, supra, n. 46. Her thesis was that in British Columbia (there the Labour Relations Board had primary jurisdiction) labour relations considerations were paramount. See also: P. Weiler, Reconcilable Differences, New Directions in Canadian Labour Law (1980), at pp. 289ff.

79. Supra, n. 47. 
Presently, unions may picket to disseminate information to the public and to peacefully dissuade others from entering the employer's premises provided that they do not do so by "acts otherwise unlawful". The latter words have been interpreted to include civil wrongs. ${ }^{\circ 0}$ Thus, interfering with contractual relations would be unlawful, even if done peacefully. The reality is that the picket line is perceived by unions as an economic weapon - if they can shut down the plant, their bargaining position is enhanced. The age-old dilemma clearly is how best to balance the interests of (1) the public in protecting it from harm against (2) the interests of the parties to union-management relations in being able to freely assemble and exercise their relative bargaining power on the picket line, if need be, to resolve their private interests. 81 The narrowing of grounds for injunctions finely tunes the balance somewhat. The economic reality of the picket line is recognized, while drawing the line at violence and destruction of property.

The response by labour will be dependent upon its perception of the extent to which the replacement problem has been resolved. Unfortunately, that perception may be coloured somewhat by s. 198(1)(a) of Bill 60 which seems to prohibit non-employees from joining picket lines. ${ }^{82}$ The thrust of the provision appears to stem from the ill-conceived belief that "outside agitators" are the cause of labour violence and, absent their presence, violence on picket lines will somehow end. It is likely that this will strike unions and other organizations such as church groups and umbrella labour organizations as offensive. Undoubtedly, the argument will arise that prohibiting peaceful participation at a picket line is contrary to s. 2(b) (freedom of expression) and s. 2(c) (freedom of peaceful assembly) of the Charter of Rights and Freedoms. The first critical question will be whether silence of the proposed provision as to the right of non-employees to picket amounts to a prohibition. Consistency with the Charter could be achieved by saying that not conferring a right expressly is different than a prohibition. On the other hand, if s. 198(1)(a) is viewed as a complete codification of who may picket (and thus a prohibition against others) there may well be conflict. Presently the test for constitutional validity would require some evidence from those seeking to assert the right that the prohibition is contrary to a well recognized, time honoured tradition; and if that is the case the government would have to seek to justify it under s. 1 of the Charter by showing it is both necessary and that the least intrusive

80. Labour Relations Act, supra, n. 12, s. 114; Edinburgh Developments Ltd., supra, n. 47.

81. Municipal employers in British Columbia, for instance, successfully lobbied for the right to strike for police and firefighters during 1973, partly because they anticipated that it would give them greater bargaining power than under, say, compulsory interest arbitration. See E.G. Fisher and H. Starek, "Police Bargaining in Canada: Private Sector Bargaining, Compulsory Arbitration, and Mediation-Arbitration in Vancouver", in B.M. Downie and R.L. Jackson, eds., Conflict and Co-operation in Police Labour Relations (1980), at p. 50.

82. Currently, s. 114(1) of the Labour Relations Act, supra, n. 12, expressly permits "anyone authorized by the trade union" to picket with the employees. S. 198(1)(a) of Bill 60 removes those entitling words. 
means have been used. ${ }^{83}$ Both of the latter are factually dubious propositions.

\section{SPIN-OFFS}

One controversial issue that neither the Report nor Bill 60 recommends reform for is spin-offs. Under most labour legislation in Canada, statutory provisions fundamentally alter two critical concepts. The first is "privity of contract" by which only the direct parties to a contract (a collective agreement) are bound by the contract. Alberta, in common with other Canadian jurisdictions, provides that the certification and obligations under a collective agreement follow the sale or other disposition of a business. ${ }^{84}$ The second concept is that of the "corporate veil". S. 133 of the Labour Relations Act permits the Board to pierce the veil and determine that two or more companies are under common control or direction. If that factual determination is made, the Board may declare that the companies are one employer for the purposes of the Act. The intent of the legislation was to prevent avoidance of collective bargaining obligations by the simple rubric of establishing a separate corporate body performing the same or related activities.

The issue of spin-offs has been of vital concern in Alberta's construction industry where the degree of "unionization" (i.e., coverage by collective agreements) fell dramatically during $1982-84$ from roughly $70 \%$ to $5-10 \%$ and currently remains at the lower level. ${ }^{85}$ The economic downturn suffered by the industry led employers to seek means of running non-union operations. The principal means by which this was achieved was a combination of setting up a different corporation and contracting out for the workforce. The result was that the strength of the spin-off provisions became a critical legal issue for construction trade unions.

In 1983-84, the government proposed to pass legislation that would have specifically authorized spin-offs in the construction industry, ${ }^{86}$ much as had been done in Saskatchewan. ${ }^{87}$ However, Board interpretations of s. 133 obviated the need for the amendments, and they were withdrawn.

In Construction and General Workers' Union, Local 92 v. H.D.C. Construction Co. Ltd. ${ }^{88}$ the Board held that a unionized firm which had converted to a "project management" operation, thereby sub-contracting all work on the project, was not an employer against whom a s. 133 declaration could be made. Subsequently, the Board heard a case in which a unionized company had created a second company to operate projects

83. The Alberta Court of Appeal in Grier v. Alberta Optometric Association (unreported, July 167, 1987) held that s. 2(b) protects expression at least when uttered in the context of an activity that is honoured as fundamental in the Canadian tradition. To justify an infringement under s. 1 requires evidence that the government objective is important and that the means used are rational and proportioned; see $R$. v. Oakes (1986) 24 C.C.C. (3d) 321 (S.C.C.).

84. Labour Relations Act, supra, n. 12, s. 133.

85. Fisher and Kushner, supra, n. 20, at p. 778.

86. Labour Relations Amendment Act, 1983 S.A., c. 82.

87. There is no equivalent to s. 124 of the L.R.A., supra, n. 12 in the Sask. Trade Union Act, R.S.A. 1978, c. T-17, as amended.

88. Unreported, No. L.R. 1655-H-14 (Alta. L.R.B.). 
similar to those done by the initial company. However, the second company subcontracted all work, and again, it was held that a s. 133 declaration would not be made. Since the second company had no employees, it could not be an "employer" under the Act, and s. 133 did not apply. ${ }^{89}$ The latter decision was upheld by the Alberta Queen's Bench as not being "patently unreasonable"so.

Applications pursuant to s. 133 also were made difficult by the Board's adoption of a policy that such applications had to made in a fully particularized manner. The particulars had to include: names of all corporations involved, the relationship alleged to exist between the corporations, particulars of business activities carried out and the involvement of each of the corporations, facts supporting the allegation of common control, and any special labour relations purposes for the granting of a declaration. Applications not providing sufficient particulars would not be processed. ${ }^{91}$ In short, the union had to reveal a virtually complete case in its application before it would be processed. Thus, it could not obtain an order for production of documents pursuant to s. 13 unless it had demonstrated an arguable case on paper.

Consequently, many construction employers made the decision to run non-union projects by the simple devices of subcontracting the work; or, if the company was bound by a no-subcontracting clause in the agreement, by setting up an intermediary company which would then subcontract out the work. The risks of doing so and being caught by a s. 133 declaration were vastly reduced by Board decisions which held that, in any event, s. 133 declarations were not retroactive in effect..$^{92}$ Accordingly, even should the attempt at spinning-off prove unsuccessful, the damages that might be awarded would be considerably less than they could have been, had retroactivity applied.

This is the background to the Report's non-recommendation. The Report simply indicates that it hopes that as a result of other recommendations (presumably the recommendations for closer union-management cooperation), the situation will improve eventually.

However, important developments have occurred since the issuance of the Report. The most important is a decision of the Labour Relations Board which modifies the existing case law. In International Union of Operating Engineers, Local 955 v. Peter Kiewit and Sons Co. Ltd., et al, ${ }^{93}$ it was determined that a construction contractor, bound by a collective agreement, had decided to set up a non-union operation. It did so by forming a second company which was a construction broker firm (i.e., project management operation engaged in no direct hiring). As such, it had no employees and subcontracted all work on the project. The second

89. Operative Plasters and Cement Masons Local 924 v. Stuart Olson Construction Ltd., et al., unreported, L.R. 1431-T-1 (Alta. L.R.B.).

90. Unreported, Edmonton No. 8303-19530, (Alta. Q.B.).

91. Labour Relations Board, Information Bulletin No. 19-85.

92. International Brotherhood of Boilermakers v. Canyon Industries (Alta) Ltd., unreported, L.R. 1809-P-20 (Alta. L.R.B.); Braunfel Engineering \& Construction Ltd and Braunfel Industries Ltd. (1983), 3 C.L.R.B.R. (N.S.) 1 (Alta. L.R.B.).

93. International Union of Operating Engineers, Local 955 v. Peter Kiewit and Sons Co. Ltd., [1987] Alta. L.R.B.R. 79 (Alta. L.R.B.). 
company was established and promptly bid successfully on a major project. The second company entered into a contract with the first by which all necessary equipment, administrative personnel and services, and supervisory personnel would be supplied. The subcontract for the workforce was awarded to a third company.

The union applied for a declaration that all three companies were a single employer for the purposes of the Act, and thus bound by the collective agreement. The Board made a number of significant rulings as follows:

1. The first and second companies were a single employer notwithstanding the fact that the second company had no employees. Overcoming this fact was that the second company virtually had no (independent) existence apart from the first. ${ }^{94}$

2. The third company would not be joined in the declaration, since it was the actual employer of the work force and enjoyed an existence separate from the two other companies. Impliedly, the Board indicated that, if the third company existed only to supply labour to the first two companies, it, too, might have been joined. Significantly, this creates an arms' length test in contracting out situations. ${ }^{95}$

3. In exercising its discretion whether or not to grant a declaration, the Board would consider potential subversion or future erosion of bargaining rights, and not just an immediately adverse consequence. This was in response to the argument advanced that the union had failed to prove that its members had been adversely affected by the corporate manoueverings. The Board held that there was a potential loss, if the union were successful in bargaining a no-subcontracting clause into the agreement during the current negotiations. ${ }^{96}$

The existing spin-off provision was a source of considerable controversy during the Committee's hearings. Construction companies generally argued for retention of the status quo, ${ }^{97}$ while unions argued for stronger legislation. ${ }^{98}$ While the lack of a recommendation initially might have been viewed as a "win" for contractors, in the light of subsequent developments the absence of a recommendation probably benefitted the unions.9

\section{CONSTRUCTION INDUSTRY \& BILL 53}

Apparently largely due to the 24-hour lockouts that occurred during 1984 , in particular, and since very few collective agreements were successfully renegotiated in construction during 1984-87, the Report singled out

94. Ibid., at pp. 103-112.

95. Ibid., at pp. 112-117.

96. Ibid., at pp. 104-107 and Peter Kiewit and Sons Ltd. and Kiewit Management Limited v. International Union of Operating Engineers, Local 955, [1987] Alta. L.R.B.R. 391, at pp. 393-394, 397-398. An oral decision delivered October 28, 1987 by Berger, J. (Q.B.) on a Motion for Certiorari set aside the latter Board decision and remitted it to the Board ([1987] Alta. L.R.B.R. (Court Challenges)).

97. Construction Labour Relations - an Alberta Association, Brief to the Labour Legislation Review Committee.

98. Alberta Federation of Labour, Brief to the Labour Legislation Review Committee.

99. This was the view clearly espoused by the construction Labour Relations Association in its Reply to the Labour Legislation Review Committee Final Report. 
this industry for special treatment. An addendum to the Report specifically directed the parties to collective agreements in the industry to realign the structure of their negotiations by May 1st, 1987. Failing this, it threatened the imposition of a more consolidated or centralized bargaining structure. ${ }^{100}$

The Government carried through on its threat during the following month when it introduced Bill 53, the Construction Industry Collective Bargaining Act. Before addressing the specifics of Bill 53, we shall focus on key recommendations and features of Bill 60 , pertaining to construction. Two key recommendations concerned the registration of employers' organizations and the treatment of very large scale (or mega) tar sands projects.

There was a consensus that the registration process be retained. ${ }^{101}$ Registration is a certification or accreditation process, and a registration certificate confers exclusive bargaining rights upon an employers' organization for all employers involved in a bargaining relationship with a union representing a particular trade, regardless of whether contractors desire this or not, as long as there is majority support in the unit for the registered employers' organization. This is a significant departure from Saskatchewan where registration was dismantled. ${ }^{102}$

Concerning mega tar sands projects, it was recommended that they not be "carved out" (i.e., exempted) from the normal application of the statutory collective bargaining regime and, therefore, be permitted to incur lawful strikes or lockouts. ${ }^{103}$ Contractors traditionally have argued that socalled carve outs create "strike havens" where striking tradesmen elsewhere can obtain employment or be "rotated through" and that their unions, in turn, could unfairly collect dues from their tradesmen working on the carved out site. ${ }^{104}$ Carve outs, however, could be created under Bill 53 (s. 2(4)), which will not apply to "any portions of the construction industry exempted by the regulations." Moreover, a project agreement reached during 1985-86 for the Syncrude plant site expansion is specifically excluded. ${ }^{105}$

Bill 53 envisages an even more broadly based bargaining structure than the previously existing one. During the past decade or so the bargaining structure has been based upon geographical regions (e.g., northern or southern Alberta or Province-wide) and single trades (e.g., electrician, plumber, bricklayer, or insulator). By contrast, certain other provinces, most notably British Columbia, had moved to more integrated bargaining structures. In British Columbia, for instance, a council of trade unions, comprising 13 building trades unions, ultimately emerged. ${ }^{106}$ Some difficulties were encountered with the B.C. council. For one, the differential

100. Final Report, supra, n. 2, Recommendations 41-42, at p. 102.

101. Ibid., at p. 102.

102. Construction Industry Labour Relations Repeal Act, S.S. 1983, c. 2.

103. Final Report, supra, n. 2, Recommendation 43, at p. 103.

104. Fisher and Kushner, supra, n. 20, p. 787.

105. Bill 53, supra, n. 4, s. 29(4)(a), concerning the Project Labour Agreement for Capacity Addition Project - April, 1985.

106. P. Weiler, supra, n. 78, at pp. 195-205. 
between bottom-end compensation packages (e.g., labourers) and the topend (e.g., electricians and plumbers) narrowed a good deal. For another, compensation packages in the institutional, commercial and industrial (ICI) segment of the general construction market proved to be excessive for residential construction. Unfortunately, attempts to negotiate a separate agerement for residential construction, to reflect labour market realities, floundered. ${ }^{107}$ Some labour economists are concerned that such a highly integrated bargaining structure as B.C.s also might not respond to differences in the demand for labour that derive from size (e.g., industrial versus institutional and commercial in ICI) or from location (i.e., rural versus urban)..$^{108}$

Despite such possible drawbacks, centralized bargaining structures seem to provide certain advantages. They typically reduce strike activity and tend to exert a dampening impact on compensation package settlements. ${ }^{109}$ These attractions presumably underpin Bill 53. It envisages the formation of "bargaining federations" among a list of designated building trades unions by September 15, 1987 (s. 8). Though not indicated, the bargaining federations could consist, for instance, of the following potentially natural groupings: "mud trades" (e.g., bricklayers, cement masons, lathers, and tilesetters), "metal trades" (e.g., plumber, boilermaker, and millwright, plus sheetmetal, electrical, and structural iron workers) and "civil trades" (e.g., operating engineer, labourer, carpenter, teamster, painter, and insulator (or thin mechanical)). ${ }^{110}$ Regulations governing the federations and other aspects of the Act (which need not be published (s. 14)) reportedly were being drafted during late June of 1987 .

The proposed bargaining structure, like B.C's, is to be two-tiered, involving a "master construction agreement" covering the entire unionized portions of construction (as defined in s. 1(1)(c)" ${ }^{\prime \prime}$ ), in addition to "subsidiary agreements." Each subsidiary agreement is to be "a specific portion of the master construction agreement that relates to a designated trade group, region or sector or any of them containing terms and conditions of employment referred to in section 3(5)"."12 The latter cover

107. P. Weiler, ibid., at pp. 206-207; Fisher and Kushner, supra, n. 20, p. 785.

108. See E.G. Fisher, An Assessment of Structured Determinants paper at 17th C.C.A. Annual Construction Labour Relations Conference, Vancouver, Nov. 20, 1986.

109. P. Weiter, supra, n. 78, at p. 202, J. Rose, Legislative Support for Multi-Employer Bargaining: The Canadian Experience (1986), 40 Industrial \& Labour Relations Review 3.

110. E.G. Fisher, supra, n. 108. Instead of several bargaining federations, one large one was adopted. (See The Rules for the Conduct of Federation Bargaining for the Federation of Alberta Construction Unions (1987) and By-Laws Construction Employers' Collective Bargaining Federation, July 16, 1987.

111. "(C)onstruction" includes construction, alteration, decoration, repair or demolition of buildings, structures, roads, sewers, water or gas mains, pipelines, dams, tunnels, bridges, railways, canals or other words, but does not include,

(i) supplying shipping or otherwise transporting supplies and materials or other products to and delivery at a construction project, or

(ii) maintenance work;

Significantly, contractor employers providing camp services related to a construction project are engaged in the construction industry (National Association of Camp Management Contractors, [1987] Alta. L.R.B.R. 588).

112. Bill 53, supra, n. 4, s. 1(1)(h). 
"the trade group and region designated by the Minister to which the subsidiary agreement applies, including (a) terms and conditions with respect to wages and benefits, and (b) any other terms or conditions to which the parties agree or that the Minister may prescribe for inclusion in the subsidiary agreement," but they are not to be "matters that are to be included in the general part of the master agreement." 11

The master construction agreement (MCA) is to include terms and conditions which respect to (s. 3(4)(a): (i) jurisdiction, (ii) hours of work and overtime, (iii) recognition, (iv) management rights, (v) travel allowance, and (vi) grievance procedure, as well as "any other terms and conditions to which the parties agree or that the Minister may prescribe for inclusion in the general part" of the MCA. ${ }^{14}$

There are several potential difficulties with those specific contents of the MCA.

(1) It is not clear whether or not a tribunal or other administrative body is to be established for resolving jurisdictional disputes. One was envisioned for over a decade in previous legislation but never was successfully implemented. ${ }^{115}$ Presumably what is contemplated is something like the Job Assignment Plan developed in British Columbia. ${ }^{116}$

(2) A recognition clause normally reiterates what is spelled out in a certificate and is essentially redundant. Most Alberta building trades unions no longer seek voluntary recognition arrangements, as was the customary practice when the bargaining climate favoured them. Partly because voluntary recognition can be unilaterally terminated by written notice, ${ }^{117}$ construction unions' bargaining relationships now generally are covered by certificates. It should be clarified whether union security arrangements also are considered to be a key aspect of recognition.

(3) A management rights clause would seem to be superfluous. In the absence of such a provision, the residual rights theory, which is supported by the vast bulk of arbitrators, ${ }^{118}$ presumably would apply. It, in turn, accords those rights unfettered by a collective agreement to management. ${ }^{119}$ Perhaps, what is contemplated here are subcontracting clauses. If not, the issue of job security does not appear to be addressed by the MCA.

(4) Travel allowance has applied to some construction sites under project agreements (i.e., agreements specific to a particular site) during the past few years but not to others. Would a travel allowance provision require the payment of travel time or related benefits on all sites? Alternatively, might the relevant provision provide no benefits and simply be reserved for future negotiation?

113. Ibid., s. 3(5). Indeed, travel pay under an agreement which expired, pending negotiation of the industry agreement were preserved by s. 12(2) of the Construction Industry Collective Bargaining Act (International Association of Bridge, Structural and Ornamental Ironworkers, Local 720 v. Northern Steel Inc. et al., [1987] Alta. L.R.B.R. 576.

114. Ibid., s. 3(4).

115. Alberta Labour Amendment Act, 1977 S.A., c. 77, ss. 160-162.1.

116. P. Weiter, supra, n. 78 at p. 204.

117. Canem Systems Ltd. (unreported, August 31, 1984) (Alta. L.R.B.).

118. E.E. Palmer, Collective Agreement Arbitration in Canada, (1983), at pp. 594-596.

119. See E.G. Fisher and L.M. Sherwood, Fairness and Managerial Rights in Canadian Arbitral Jurisprudence (1984), 39 Relate Ind. 538. 
(5) Requiring uniform grievance procedures for each bargaining federation might be counterproductive, unless the objective is to provide a forum for resolving jurisdictional disputes under the MCA. Unions and contractors typically negotiate grievance handling mechanisms which are tailored to their settings and interests. Moreover, concessions presumably were granted to achieve mechanisms specially suited to each trade. Should the parties fail to agree, a set of "model clauses" would be deemed by statute to be part of the agreement. Since the model clauses automatically apply, why should the parties be required to negotiate a grievance procedure? ${ }^{120}$ Moreover, why should not individual bargaining federations be allowed to develop their own grievance mechanisms? An industry-wide grievance mechanism like the one proposed, however, should be capable of dealing with jurisdictional disputes, since all the building trades unions would be parties to the agreement.

The MCA is to have a duration of "at least 5 years from the date on which it is concluded"' while subsidiary agreements are to last " 2 years from the date on which they are concluded" (s. 3(6)). The MCA is to be completed "by September 15, 1987 or any later date prescribed by the Minister (s. 8). To reiterate, the subsidiary agreements are to be a part of the MCA. This is important because of the kind of dispute resolution machinery Bill 53 establishes.

The dispute resolution machinery, like the establishment of the bargaining structure, can be highly influenced or essentially determined by the Minister. Significantly, it envisages the reaching of settlements, possibly through lawful work stoppages, and, perhaps, ultimately through interest arbitration, at the Minister's discretion (s. 8). The uncertainty surrounding interest arbitration clearly is intended to induce the parties to reach their own accord, as is the option of having "final offer selection" (s. 10(2)), instead of or in combination with conventional interest arbitration (s. 10(1)). Arbitration would be conducted by what is termed a construction industry disputes resolution tribunal (ss. 13 and 9). Regardless of how agreement negotiations ultimately are resolved, wages and benefits clearly will be key issues. Arbitration could be ordered, for instance, should the parties fail to bargain in "good faith", as required by Bill 53 (s. 4(b)). An additional safeguard against bad faith bargaining is that the provision (s. 6) permitting one side to submit a proposal directly to the other side's constituency or principals, but only once during either MCA or subsidiary negotiations.

Significantly, strike or lockout votes would not be conducted as simple (or single) majority votes. Instead, they would entail a modified double majority test, before a lawful work stoppage could take place. A successful strike vote would require (s. 7(b)) that "(i) at least $60 \%$ of the trade unions that represent employees who are eligible to vote are in favour of the strike, and (ii) at least $60 \%$ of the total number of persons eligible to vote and voting vote in favour of the strike." A successful lockout vote would require (s. 7(a)) that "at least $60 \%$ of the employers who are affected by the dispute who are eligible to vote and voting, and who collectively employ at

120. Nevertheless, the arbitrability of disciplinary actions, including discharges, solely for just cause should be clarified, as explained below. 
least $60 \%$ of the employees calculated in accordance with the regulations, vote in favour of the lockout.' Bill 53, therefore, reflects a desire to see collective agreements in construction (re)negotiated in the absence of lawful work stoppages. Even if they occur, the MCA ultimately could be imposed upon the industry through interest arbitration at the Minister's behest.

Bill 53 preserves the status quo with respect to "spin-offs" or related companies under common ownership and control, and it supports certification as the chief means for establishing bargaining relationships. It does not envisage votes by employees at union and non-union arms of essentially the same firm to determine majority support, as a previously enacted, yet subsequently rescinded bill (i.e., Bill 110) ${ }^{121}$ did.

Rather, it would seem to grant somewhat longer than a two-year amnesty on spin-off declarations to those firms that met one of two conditions. Either they were not subject to an existing obligation to bargain collectively with a trade union designated under the Act (s. 11(4)(a)), or they were not subject to a collective agreement or settlement with one of the designated trade unions for construction work (s. 11(4)(b). This amnesty would apply "from the date this Act comes into force" (s. 11(4)), and the Act "shall be deemed to have come into force on June 5, 1987" (s. 15). It appears that both legitimate and sham spin-offs would be protected and that spin-off declarations gained after June 5, 1987 might be rendered nullities by the retroactivity provision.

There seems to be an implicit gamble in the amnesty provision that a construction upswing will occur with the next two years or so, thereby reducing the incentives for construction firms to operate both union and non-union arms. The matter of so-called reverse spin-offs (i.e., of an arm operating with a collective agreement from an arm without one) does not appear to be addressed. Nevertheless, should a certificate be issued to a related operation after the Act comes into force, then the labour board could issue a single employer declaration, covering both the operation subject to the certificate and the related operation without a certificate.

Key features and our overall impressions of Bill 53 are as follows. (1) Bill 53 obviously gives vibrancy to existing and future bargaining relationships in the construction industry. It clearly envisages the reaching of settlements during the collective bargaining process. The settlements would cover the entire industry at one level and smaller trade-based segments or sectors at the subsidiary level. Given the general lapsing of collective agreements in the industry during 1984-87, this development should be welcomed especially by building trades unions, which should begin collecting larger union dues thereafter. (2) The move to bigger or broader bargaining tables is consistent with the trend across Canada and should dampen settlements. A contractors' spokesman, however, suggested that interest arbitration would not have the full moderating impact of freely negotiated settlements in today's prevailing economic climate..$^{122}$ (3) The proposed bargaining structure must be implemented carefully. In particular, bargaining tables should be structured, so that neither minority views nor underlying market

121. Bill 110, supra, n. 86.

122. New Bill would end 25 hour lockouts, Edmonton Journal, June 6, 1987. 
conditions or other special conditions become swamped by majority views and, therefore, effectively neglected in settlements. In addition, the content of the MCA must be clarified. (4) The considerable discretion which Bill 53 provides the Minister in establishing not only the bargaining structure but also in dispute resolution could be a bane or a boon. On the one hand, it could become a license for excessive governmental interference into the parties' generally private affairs. On the other hand, this broad discretion, coupled with the uncertainty of its use, could provide a key inducement for the parties to resolve their disputes by themselves. (5) Bill 53 provides for two potentially effective safeguards against breaches of the duty to bargain in 'good faith', which it embodies: required votes on proposals by the other side and interest arbitration. (6) The status quo which Bill 53 clearly maintains for spin-offs seems to be predicated upon the premise that Alberta's construction industry will experience an upswing during the next two years. In effect, Bill 53 says that if a firm was able to successfully spin off a related firm to date, it will be permitted to operate on this basis, unless a bargaining relationship be established subsequently. The two-year or more moratorium on single employer declarations, together with a two-year term for possibly imposed subsidiary agreements and a five-year term for the MCA, seem to be based upon the premise that there will be an upturn in Alberta's construction industry in the interim. (7) Like any other statutory retrofit to a previously developed system, the provisions of Bill 53 may become viewed as being time-bound in future and, therefore, have to be jettisoned.

\section{GRIEVANCE PROCEDURE}

According to the Labour Relations Act, every collective agreement must contain a method of dispute resolution with respect to the interpretation, application, operation or contravention of the collective agreement. ${ }^{123}$ In the absence of such provisions in the collective agreement, s. 120 of the Act provides model clauses deemed to be part of the agreement in respect of those matters upon which it is silent. The model clauses establish a two-step grievance handling procedure. The first one consists of a meeting between the parties, and, failing a resolution of the difference, the second one comprises arbitration before a single arbitrator. There are no strict time limits for rendering an arbitration decision.

The Report and Bill 60 propose further mandatory provisions providing for expedited arbitration. ${ }^{124}$ In particular, where a grievable termination, lay-off or suspension occurs and the employer has been provided with seven calendar days to respond to the grievance, then the matter must proceed directly to arbitration. If within the seven days the matter has not been resolved, or an arbitrator appointed by the parties, then the Director of Mediation is to appoint an arbitrator who must meet and render a written decision within fourteen calendar days. An alternative recommendation is that the Labour Relations Board handle these grievances. ${ }^{125}$

123. Supra, n. 12, s. 118.

124. Final Report, supra, n. 2, Recommendations $46-47$ at p. 104; Labour Code, supra, n. 3, s. 285.

125. Final Report, ibid., Recommendation 49 at p. 104. 
Currently, most collective agreements replace the model clauses with a more elaborate, elongated grievance handling mechanism tailored to suit them and their industry. The typical collective agreement establishes a grievance procedure with three to four levels to it. The initial steps provide for discussion in order to try and resolve the matter, and the final step is arbitration. The parties must then appoint nominees to an arbitration board; the nominees then attempt to agree upon a Chairperson and if they fail to reach agreement, an application may be made to the Minister of Labour to appoint one. Dates for hearing are then established which suit the convenience of the parties, their counsel and the board members. Following a hearing or hearings, a written decision is rendered. Often the agreement provides for a time limit for the decision, but in practice this is normally waived by the parties. Significantly, only about $10 \%$ of all grievances are resolved through arbitration. ${ }^{126}$ Thus, it would appear that the current structure is successful in resolving grievances. Furthermore, a recently established grievance mediation program by Alberta Labour has been added to the established procedures. ${ }^{127}$

The elaborate, elongated procedures often incorporate delay which can unduly prolong discipline and lay-off cases. Accordingly, the recommendations for expedited arbitration are useful. They benefit the employee by providing for a quick determination of job status, opening the possibility of a quick return to work rather than looking for alternative work during the period of arbitration. There is a benefit to the employer in that the issue of damages (assuming a successful grievance) should be remarkably simplified. The period of possible damages would be vastly reduced and the issue of mitigation of damages virtually eliminated. ${ }^{28}$ Moreover, expedited arbitration should force the parties to more readily address the issues at hand and, at a minimum, hopefully agree upon a common set of facts for arbitration.

This proposal is potentially problematic in at least two ways. At a procedural level it begs the following issues: will it provide sufficient time to prepare a case for arbitration, particularly if numerous witnesses are involved; will counsel be available within that short time span; and, if not, will the issue of the right to choice of counsel arise?

One fortunate difference between the Report and Bill 60 is that the Report seemed to establish a pre-condition to the operation of the expedited arbitration provisions that it involve a "grievable" termination, lay-off or suspension. ${ }^{129}$ No such qualification appears in Bill 60. Arbitrability (i.e., whether or not the matter is or can be the subject of arbitration) may fail to exist, for instance, where time limits have been exceeded, an employee quit and, therefore, was not discharged or the proper procedures for processing the alleged grievance were not followed.

Significantly, the issue of arbitrability seems to have been conclusively resolved for those few collective agreements not expressly providing for

126. Weatherill in T. Christian, ed, Grievance Arbitration Workshop (1980) at pp. $56 \mathrm{ff}$.

127. W. Pangrass in C. Rigg and A. Ponak, eds., Proceedings of the 1985 Calgary Arbitration Conference, at pp. 178-182, 190, 192.

128. See D.J.M. Brown and D.M. Beatty, Canadian Labour Arbitration (1984), at pp. 62-68.

129. Final Report, supra, n. 2, Recommendation 47, at p. 104. 
arbitration for dismissals or suspensions. Three lines of cases have existed in Alberta. A minority line held that dismissal grievances always are arbitrable. ${ }^{130}$ Another line held that, if a right to grieve can be reasonably inferred into the agreement, having regard to the contract language as a whole, it is arbitrable. ${ }^{131}$ Yet another line held that, absent specific language or necessary implication, these grievances are not arbitrable. ${ }^{132}$ The Alberta Court of Appeal upheld the last line of cases as not being patently unreasonable but declined to opine as to which approach was the correct one..$^{133}$

In the light of St. Anne Nackawick ${ }^{134}$ and Oliva v. Strathcona Steel ${ }^{135}$ the previous minority view could well become the dominant view. The reason is that the only avenue of recourse in these matters under a collective agreement is through its grievance handling mechanism, as held by one Alberta arbitrator. ${ }^{136}$ In any case, relatively few preliminary objections as to arbitrability tended to be upheld during 1982-84 in Alberta. ${ }^{137}$

The duty of fair representation poses another major problem. Unions are both by common law $w^{138}$ and by statute required to "fairly represent" the grievor. ${ }^{139}$ Specifically, a union may not discriminate, act arbitrarily or in bad faith in the determination of whether or not to proceed to arbitration. ${ }^{140}$

A union, however, also has legitimate concerns with respect to the expenditure of its resources and owes an obligation to the employer not to file and proceed with frivolous grievances. ${ }^{141}$ These conflicting interests assume added significance in cases involving "critical job interest" issues (e.g., dismissal, lay-off and suspension). ${ }^{142}$ The objective test of reasonable diligence and full inquiry has been applied in such cases. ${ }^{143}$ Expedited

130. Supra, n. 128, at p. 331.

131. Western Union of Brewery, Winery and Distillers Workers v. Carling O'Keefe (1982), 11 L.A.C. (2d) 374 (Beattie); Re G.C.W.U. Local 424 v. A.C. Horn Co. (1953) 4 L.A.C. 1524 (Laskin).

132. Lackerbie and Hole Western Ltd. v. United Plumbing and Pipe Fitting Union, Local 496 (1983), 9 L.A.C. (3d) 211 (Fisher); Sherwood Park Separate School Board No. 105 v. C.U.P.E., Local 1961, (unreported, 1983) (Jones).

133. United Nurses of Alberta, Local II and Thomas v. Misericordia Hospital (1983), 46 A.B. 172 (Alta. C.A.). Moir, J. in a concurring judgment indicated that he preferred the view that the reserved right was the right to discharge for cause which would have rendered the matter arbitrable (at p. 181).

134. Ste. Anne Nahuie Pulp \& Paper Co. Ltd. v. Canadian Paper Workers Union, Local 219, [1987] 1 S.C.R. 704 (S.C.C.).

135. (1987) 74 H.R. 46 (Alta. C.A.).

136. Carling O'Keefe Breweries of Canada Ltd. v. W.U.B.B., W.D.W., Local 287, (1982) 4 L.A.C. (3d) 374. In Noa v. Burns Meat Ltd. (1986), 47 Alta. L.R. (2d) 144 (Alta. Q.B.), Mason, J. held that this principle applies only if a collective agreement actually existed at the material time.

137. See R. Bradford and E.G. Fisher, Preliminary Objections in Alberta Labour Arbitrations, Working Paper (1987).

138. Canadian Merchant Service Guild v. Gagnon et al, 84 C.L.L.C. 14,043 (S.C.C.).

139. Labour Relations Act, supra, n. 12, s. 138(1).

140. Gagnon, supra, n. 138, at p. 12,188.

141. Rayonier Canada Ltd., [1975] 2 C.L.R.B.R. 196 at pp. 200-205. (B.C.L.R.B.).

142. Martin v. Alberta Food and Commercial Workers Union, Local 397 (unreported, L.R. 2280M-2, Sept. 11, 1985 (Alta. L.R.B.) Information Bulletin No. 21-87, at pp. 3-4.

143. Information Bulletin, ibid., pp. 3-6. 
arbitration decisions compel not only quick arbitration but also a quick determination by the union whether they wish to advance the case to arbitration. Consequently, the full inquiry standard should bear the time restrictions in mind. The Labour Relations Board could be asked for a speedy determination whether a decision not to proceed would deny fair representation. A speedy determination is currently possible under the Board's procedures. ${ }^{144}$ This may be further expedited by the Report's general recommendation for the streamlining of Board procedures and its specific recommendation that a nonbinding opinion could be solicited from a single member or three member panel of the Board. ${ }^{145}$ However, the difficulty remains whether notice to the grievor can be achieved within the seven days and whether sufficient information might be available for the Board or members to adequately assess the merits of the case.

Significantly, the Report recommends that a decision made "in good conscience" not to proceed to arbitration would be a defence to an alleged breach of the duty. ${ }^{145}$ Unfortunately, it is not clear that "in good conscience" can be distinguished from the current test of acting "in good faith.' Both tests would require an informed decision by the union. In the final analysis, the combination of good faith, informed decisions, and compressed time limits probably would force unions to advance questionable critical job interest grievances to arbitration. Bill 60 does not carry forward with the "good conscience" defence. Rather, it provides that, if a union breaches the duty of fair representation, the Labour Relations Board may extend the time for the taking of any step in the grievance procedure, provided the employer would not be substantially prejudiced (s. 129(b)(vi)). This will not be popular with employers, for it extends the time limits for possible liability for damages or reinstatement of an employee. At the same time, it would potentially limit the financial liability of the union. It is a measure that is available in other jurisdictions ${ }^{147}$ but, as yet, it is too soon to determine whether such a provision will give rise to an increase in fair representation cases.

The expedited arbitration regime appears to be modelled after the Ontario system. ${ }^{148}$ It differs from the Ontario scheme by providing a more rigid and shorter time frame and, unlike its Ontario counterpart, seems to override rather than supplement the grievance procedure in a collective agreement. Overriding would obviate some of the difficulties encountered in Ontario, including the switching of procedures once the composition of an arbitration board has been established either in part or in whole..$^{149}$ However, the truncation of time frames in Alberta could cause difficulty. The Report tentatively proposes (but Bill 69 does not) that Labour Relations Board members handle such grievances. ${ }^{150}$ This method, which is

144. Information Bulletin, ibid., at p. 7; Labour Relations Act, supra, n. 12, ss. 21, 141.

145. Final Report, supra, n. 2, Recommendation 54, at pp. 105-106.

146. Ibid., Recommendation 50, at p. 104.

147. Canada Labour Code, supra, n. 40, s. 289(a); Ont. Labour Relations Act, supra, n. 40, s. 89(4); B.C. Labour Code, supra, n. 23; s.

148. Labour Relations Act, supra, n. 25, s. 45.

149. Adams, supra, n. 21, pp. 684-687.

150. Final Report, supra, n. 2, Recommendations 49, at p. 104. 
available in Ontario (for the construction industry) and Manitoba, ${ }^{151}$ would require the mixing of functions. That is, Board members, who are required to administer the statute, would be required to administer collective agreements. The Board traditionally has shied away from the latter function. ${ }^{152}$ Presumably, either the composition of the Board would have to be expanded to include experienced arbitrators, or the roles of Chairman and Vice-Chairman would have to be expanded to fulfill this function. In view of its absence from Bill 60, it is an option unlikely to be adopted in Alberta.

\section{CONCLUSION}

As the outgrowths from the legislative review process of the Reid Committee, Bills 53 and 60 represent essentially a package deal, each component of which is based upon a particular premise or set of them. Honest, legitimate attempts clearly were undertaken to correct certain perceived inadequacies in the functioning of Alberta's labour relations system, especially collective bargaining. Solutions to the perceived deficiencies generally were sought elsewhere (e.g., in Ontario, British Columbia, Great Britain, the U.S., West Germany, Japan, New Zealand, and Australia). External solutions beg the question of the extent to which they can be institutionally transplanted in Alberta.

Unfortunately, should certain underpinnings be found to be weak, the legislation will require revamping, thereby presumably upsetting the set of concessions upon which the Final Report and, consequently, the two bills, especially Bill 60 , were based. The legislative review process and proposals appear to have been placed on the horns of a dilemma customarily encountered in such circumstances: to what extent should there be either legislated solutions or government intervention in the labour relations arena and specifically at the bargaining table. In terms of legislated solutions, the improved communictions proposal seems to be both somewhat ill-defined and ill-conceived, in the sense that "You can lead a horse to water, but you can't make it drink:" Furthermore, Alberta Labour's Preventive Mediation program was not evaluated before proposing the improved communications recommendation. By contrast and at first blush, the predilection revealed in Bill 53 seems to be for a high degree of governmental involvement.

It remains to be seen to what extent the Minister will use the various tools, especially interest arbitration, placed in his arsenal of weapons. An overreliance upon interest arbitration, for instance, can have a debilitating impact upon the parties' own competence and, indeed, resourcefulness at the bargaining table. ${ }^{153}$ Similarly, an overreliance upon mediation or enhanced mediation, including mediation boards, could prove to be dysfunctional. The previously existing two-stage compulsory conciliation

151. Ont. Labour Relations Act, supra, n. 25, s. 124; Man. Labour Relations Act, supra, n. 40, s. 113.5.

152. See Labour Relations Act, supra, n. 12, s. 21; Electrical Contractors Association of Alberta v. I.B.E.U. (unreported, L.R.B. 8856 D) (Alta. L.R.B.).

153. In one extreme case, the City of Vancouver and its police union, for instance, went to arbitration ten straight times during the 1960's. See E.G. Fisher and H. Starek, supra, n. 60, at p. $\mathbf{5 1 .}$ 
procedures, their antecedants, were found to be rather costly, as well as ineffective, in the sense that the parties "built them into their bargaining strategies." That is, they simply would allot so much money (e.g., 5 cents per hour) to the first stage and a bit more to the second stage, if it were forthcoming. Significantly, the more often mediators offer proposed settlements, the less effective they will be in getting the parties to negotiate through them, for the parties will be waiting to find out the mediator's proposal, before "getting down to brass tacks". ${ }^{154}$ It was for these and other reasons that the compulsory two-stage conciliation procedures were jettisoned from Alberta's labour legislation in 1980.

Four key premises in the Report and bills seem to be the following: (1) that lawful strikes or lockouts represent failures of the system, (2) that if a sufficient number of roadblocks are placed along the road to lawful work stoppages, the underlying conflicting interests and issues in dispute will be resolved, (3) that the parties to negotiations are better off knowing all the potential issues in dispute at the outset, rather than encountering some of them later on at the table, and (4) that interest arbitration (or at least the threat of it) is an inherently better method for resolving interest disputes in construction than are lawful work stoppages.

Concerning the first premise, lawful work stoppages (or the threat thereof) can serve useful functions in collective bargaining. They can "clear the air" and, more importantly, induce participants in negotiations to change their "mind sets" in such a manner that they become prepared and willing to enter into an agreement. It is the costs, including the financial stress of the lawful work stoppage, that can bring about such a changed state of mind and approach to negotiations. Perhaps even more importantly, since $90 \%$ of all agreement (re)negotiations are completed without resorting to a strike or lockout, it also is the threat of the sanction (i.e., the lawful work stoppage or arbitration), which induces concessions at the bargaining table. ${ }^{\text {ss }}$

The placing of additional roadblocks along the path towards settlement could backfire. It could impede the parties from generating all-important momentum at the table and encourage the parties to begin believing an unhealthy dose of their own rhetoric. This, in turn, typically results in the parties' suffering from "tunnel vision" in the later, more crucial stages of negotiations when open-mindedness and flexibility are called for ${ }^{156} \mathrm{Collec}-$ tive bargaining can be difficult enough without possibly placing extra unnecessary "boulders" along the path towards a settlement.

As to knowing all potential items in dispute at the outset, this would force the parties to develop long "laundry lists" of proposals, including some for in-strike negotiations, to protect themselves against any unforeseen contingencies. With both sides taking even more proposals to the bargaining table than they currently do, negotiations presumably would become even more complex and protracted. Moreover, it is naive to assume that the parties would have such clairvoyance.

154. Maggiolo, supra, n. 62, at p. 179.

155. The Suncor Team, Proceedings of the 11 th Jasper Conference (1987), at pp. 37-52 and Final Report, supra, n. 2, at pp. 8-9.

156. See for example, E.G. Fisher, G. Bourgeois and R. Purdy, A Decision Framework for Labour Negotiations Under Uncertainty, Working Paper (1986). 
Interest arbitration, as practiced, for example, in Australia and New Zealand, is not necessarily the panacea some observers believe it to be. Interest arbitration produces imposed decisions which probably are less tailored to the needs and desires of the parties than a settlement they jointly fashioned at the table. Indeed, one of the reasons that parties sometimes avoid arbitration is that one or both of them encountered substantial difficulty in attempting to live with a previous award. Moreover, compulsory interest arbitration in New Zealand and Australia has not eliminated (unlawful) work stoppages. ${ }^{157}$

The recommendations and two bills, of course, tend to benefit both sides, as a part of the package deal. If implemented as they currently stand, employers would be afforded greater opportunity for resisting organizing campaigns. Whatever related firms they have established generally would be able to continue operating, most notably for at least roughly two years in construction. Building trades and other unions most likely would benefit from the statutory bridging clauses, especially when confronted with concession bargaining during a downswing like the current one. Construction unions also have the opportunity of having arbitrated settlements, instead of having to engage in strike and picketing or face lockouts. The revamped, broadly based bargaining structure in construction should serve the public and, perhaps, both sides better than the previous bargaining structure based upon single trades (also over a particular geographical area). Both sides also should be better served through the proposed expedited grievance arbitration procedures, provided that major mechanical problems do not surface later. The scheme for paying replacement workers was identified as being highly vulnerable to changing market forces. We suggested the possibility of arbitration where the bargaining framework had been impaired by either or both sides.

Certain arguably critical issues were not addressed either as fully as they should have been or at all. Significantly, little consideration seems to have been given to the issues of what constitutes an essential service, and which groups of workers, therefore, should be permitted to engage in lawful work stoppages. School teachers, for instance, can strike, but instructors at technical institutes cannot under current statutes. The merger of statutes falls short of what might be ideal. Only the Employment Standards Act ${ }^{158}$ and the Labour Relations Act are to be merged into the new Code. The labour relations part of the code, however, will not govern groups whose collective bargaining is regulated by other statutes (e.g., instructors at technical institutes and colleges, university professors, provincial government employees, and police). There are additional anomolies or inconsistencies. For example, university professors do not have a duty to bargain in good faith under their regimes of compulsory interest arbitration, but provincial government employees do under their compulsory interest

157. D. Smith, Interest Arbitration: The Australian Experience in P. Weiler (ed.) Interest Arbitration (1981) at pp. $185 \mathrm{ff}$.

158. R.S.A. 1980 , c. E-10.1 as amended. 
arbitration framework. ${ }^{139}$ The public should benefit from a merger of the Public Service Employee Relations Board with the Labour Relations Board, which reportedly is forthcoming. It also will benefit from the proposed forum for ongoing discussions about Alberta's industrial relations system and her regional economy, provided that a consensus can be developed and its focus is on the long term functioning of the system.

In the final analysis, the Report represents a commitment to the kind of industrial relations systems that historically have existed in Canada's provincial and federal jurisdictions, except for one important change in direction. There seems to be a reversion to much greater reliance upon third party intervention (e.g., mediators, enhanced mediators and mediation boards) and a pronounced shift towards the Australian or New Zealand systems of compulsory interest arbitration. If ultimately fully implemented, as could occur under our constitution, ${ }^{160}$ this development clearly will be placed under close scrutiny by all concerned: the parties to bargaining relationships, government, the public, and, of course, academics. The 1986-87 Committee probably was not the last such committee or task force, for what presumably should be striven for is a Labour Code which will balance out the swings in Alberta's economy. After all, outcomes at the bargaining table are largely driven by the performance of Alberta's regional economy.

159. The Public Service Employees Relation Act, R.S.A. 1980, c. P-33, as amended imposes the duty by s. 39(3), while the Universities Act, R.S.A., 1989, c. U-5, as amended is silent on the point. A previous task force had suggested correcting the anomolies and inconsistencies associated with having several different acts regulating collective bargaining in the Province. See A. Melnyk, C.B. Williams and E.G. Fisher, The Law and the Alberta Labour Management Relations System (1982), at pp. 389-393.

160. In Ref. re. P.S.E.R.A., supra, n. 28, the Supreme Court held that compulsory interest arbitration was not contrary to freedom of association as provided for by the Charter of Rights and Freedoms. 